\section{JURNAL ABDIMAS

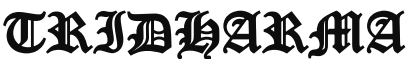

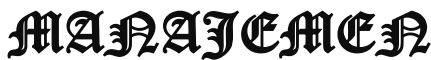

P-ISSN 0000-0000, E-ISSN 0000-0000

Jurnal ABDIMAS Vol. 1,No.1, Agustus 2019, Hal (84-91)

@Prodi Manajemen Fakultas Ekonomi Universitas Pamulang

Email: abdimasjurnal.unpam@gmail.com Telp: (021) 741-2566

\title{
PENGGUNAAN MANAJEMEN WAKTU TERHADAP PENINGKATAN PRESTASI BELAJAR DI SMP ARAISIYAH
}

\author{
Veta Lidya Delimah Pasaribu, Risza Putri Elburdah, Eko Sudarso,Gina Fauziah \\ Dosen Ekonomi Fakultas Ekonomi Universitas Pamulang \\ Email \\ Dosen01889@unpam.ac.id, dosen01022@unpam.ac.id, \\ dosen02070@unpam.ac.id, dosen01585@gmail.com
}

\begin{abstract}
ABSTRAK
Pengabdian ini berjudul Penggunaan Manajemen Waktu Terhadap Peningkatan Prestasi Belajar Di SMP ARRAISIYAH Pamulang,Tangerang Selatan.

Tujuan pengabdian ini adalah untuk membantu memberikan arahan kepada anak-anak SMP Arraisiyah mengenai manajemen waktu terhadap peningkatan prestasi belajar serta membuka paradigma mengenai dampak buruk media sosial tanpa manajemen waktu yang baik terhadap prestasi belajar. Metode pelaksanaan pengabdian ini dilakukan dalam beberapa kegiatan yaitu tahap survei yaitu sosialisasi dilakukan dengan menyusun berbagai hal yang akan disampaikan pada saat kegiatan pengabdian yang akan dilakukan yang meliputi: penyusunan materi yang akan diberikan, penyusunan jadwal pemberian materi, pembagian tugas tim pengabdian dan survei ke lokasi pengabdian. Tahap sosialisasi yaitu sebelum kegiatan pengabdian dilaksanakan terlebih dahulu dilakukan tahap sosialisasi yaitu melakukan silaturahmi dengan pihak sekolah, menyampaikan maksud dan tujuan pengabdian ini. Pada tahap ini juga dilakukan jalinan kerjasama dan menentukan jadwal kegiatan pengabdian. Tim pelaksana kegiatan pengabdian pada masyarakat adalah dosen Fakultas Ekonomi jurusan manajemen sebanyak 10 orang. Tim pengabdian memberikan materi tentang Penggunaan Manajemen Waktu Terhadap Peningkatan Prestasi Belajar di SMP Arraisiyah Pamulang,Tangerang Selatan.

Kesimpulan dari pengabdian ini adalah para siswa belum memahami dengan baik mengenai manajemen waktu dalam kegiatan pembelajaran. Selain itu para siswa mengaku bahwa lebih banyak menghabiskan waktu belajarnya untuk mengakses sosial media yang tidak berhubungan dengan pendidikan. Harapan kami dengan pengabdian ini dapat membuka wawasan bagi para siswa bahwa manajemen waktu dalam peningkatan prestasi harus dilakukan sejak dini dan dilakukan dengan disiplin.
\end{abstract}

\section{Kata Kunci: Manajemen Waktu, Prestasi Belajar}




\section{JURNAL ABDIMAS

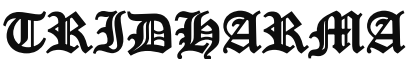

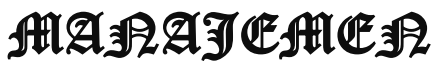

P-ISSN 0000-0000, E-ISSN 0000-0000

Jurnal ABDIMAS Vol. 1,No.1, Agustus 2019, Hal (84-91)

@Prodi Manajemen Fakultas Ekonomi Universitas Pamulang

Email: abdimasjurnal.unpam@ gmail.com Telp: (021) 741-2566

\begin{abstract}
ABSTRAC
This dedication is entitled The Use of Time Management Against Improvement of Learning Achievement in SMP ARRAISIYAH Pamulang, South Tangerang.

The purpose of this service is to give direction to Arraisiyah Middle School children on time management towards improving learning achievement and to open a paradigm regarding the adverse effects of social media on learning achievement. The method of implementing this service is carried out in a number of activities, namely the survey stage, namely the socialization carried out by compiling various things to be delivered at the time of service activities that will be carried out which include: preparation of material to be given, preparation of material delivery schedule, division of task team and survey to the location devotion. The socialization phase is before the community service activities are carried out first, the socialization phase is to do a friendly meeting with the school, conveying the aims and objectives of this service. At this stage also carried out the fabric of cooperation and determine the schedule of service activities. The implementing team of community service activities is 10 lecturers at the Faculty of Economics majoring in management. The team provided material on the Use of Time Management for Improving Learning Achievement in Arraisiyah Pamulang Middle School, South Tangerang.

The conclusion of this dedication is that students do not understand well about time management in learning activities. In addition, students claimed that they spent more time studying to access social media that was not related to education. Our hope with this dedication can open insight for students that time management in improving achievement must be done early and carried out with discipline.
\end{abstract}

\title{
Keywords: Time Management, Learning Achievement
}

PENDAHULUAN

Peranan manajemen waktu sangat diperlukan dalam kegiatan belajar, karena manajemen waktu merupakan salah satu faktor intern yang mempengaruhi belajar. Manajemen waktu yang baik merupakan motor penggerak dan pendorong bagi individu untuk belajar, sehingga didalam belajar individu akan lebih bersemangat dan tidak lekas bosan dengan materi pelajaran yang dipelari dan seiring dengan hal ini dapat meningkatkan prestasi belajar. Serta prestasi belajar yang rendah kemungkinan dalam cara belajar yang diterapkan kurang baik dan kurangnya menghargai waktu atau manajemen waktu belajarnya yang tidak baik. Manajemen waktu merupakan salah satu faktor internal yaitu suatu proses mengelola diri sendiri. 


\section{JURNAL ABDIMAS

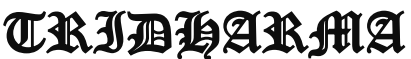

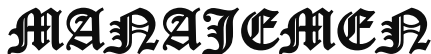

P-ISSN 0000-0000, E-ISSN 0000-0000

Jurnal ABDIMAS Vol. 1,No.1, Agustus 2019, Hal (84-91)

@Prodi Manajemen Fakultas Ekonomi Universitas Pamulang

Email: abdimasjurnal.unpam@ gmail.com Telp: (021) 741-2566
Sisi menarik disini adalah ketidakmampuan yang diperlukan untuk mengatur diri sendiri, yakni kemampuan merencanakan, mendelegasikan, mengatur dan mengontrol. Soeharso (dalam Irianto, 1990) mengemukakan bahwa waktu manusia sehari-hari dapat dikelompokkan menjadi tiga yaitu : waktu bekerja, waktu memelihara diri dan waktu luang. Waktu bekerja adalah waktu yang digunakan manusia untuk mencari nafkah agar dapat memenuhi kebutuhanya, sedangkan untuk remaja, waktu kerja dapat diidentikkan dengan waktu belajar disekolah. Waktu untuk merawat diri agar dapat hidup dengan penampilan yang layak. Waktu luang adalah waktu diluar aktifitas bekerja atau belajar maupun pemeliharaan diri.

Pemahaman manajemen waktu perlu diukur agar dapat dievaluasi atau diperbaiki. Menurut Hasan (1991: 78), pemahaman diukur melalui tiga aspek pemahaman yaitu: a) pemahaman sebagai bentuk penerimaan; b) respon; dan c) penilaian terhadap suatu objek. Pengukuran pemahaman manajemen waktu melalui bimbingan kelompok dilakukan dengan menggunakan tiga cara yaitu dengan melihat penerimaan siswa ketika mendapat layanan tentang manajemen waktu, bagaimana respon siswa dalam menanggapi, dan memunculkan ide-ide baru ketika pelaksanaan kegiatan, serta bagaimana penilaian siswa dalam menyelesaikan suatu permasalahan terkait manajemen waktu secara logis
Masa remaja memiliki tugas perkembangan yang harus dicapai agar remaja dapat berkembang dengan optimal. Tugas perkembangan tersebut antara lain berkaitan dengan perkembangan etika, nilai, kecerdasan intelektual, emosi, dan spiritual (Santrock, 2007: 20). Pada masa remaja seringkali terjadi masalah kesulitan manajemen waktu karena tidak mempunyai pemahaman mengenai manajemen waktu. Ketidakmampuan dan ketidakpahaman dalam memanajemen waktu dapat menimbulkan dampak buruk bagi siswa yaitu banyak kesempatan yang terbuang sia-sia. Permasalahan kesulitan memanajemen waktu sering terjadi pada masa remaja. Siswa Sekolah Menengah Pertama (SMP) merupakan masa transisi antara masa anak-anak dan masa dewasa, pada masa ini remaja sangat rawan oleh pengaruh-pengaruh negatif, namun di samping itu remaja merupakan masa yang baik dan mempunyai potensipotensi untuk dikembangkan dan diarahkan menuju masa perkembangan yang sehat. Manajemen waktu yang benar diperlukan dalam kehidupan remaja karena secara sosiologis, remaja berada pada keadaan yang rentan terhadap pengaruh-pengaruh eksternal. Masa remaja merupakan masa d imana proses pencarian jati diri sedang dilakukan sehingga pada masa ini remaja mudah sekali terombang-ambing dan masih merasa sulit mengambil keputusan dalam kehidupan secara mandiri. Remaja mudah terpengaruh oleh gaya hidup masyarakat di sekitar dan pada 

JURNAL ABDIMAS
P-ISSN 0000-0000, E-ISSN 0000-0000

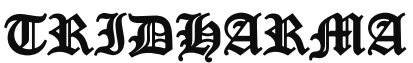
Jurnal ABDIMAS Vol. 1,No.1, Agustus 2019, Hal (84-91)
AIA
Email: abdimasjurnal.unpam@gmail.com Telp: (021) 741-2566

kelompok teman sebaya. Kondisi kejiwaan yang labil mengakibatkan remaja mudah terpengaruh oleh lingkungan

Pemahaman siswa tentang manajemen waktu akan membentuk pribadi yang disiplin. Siswa harus terlatih dalam mengatur dan mengalokasikan waktu setiap hari. Pengaturan waktu yang baik membuat siswa mampu memisahkan kegiatan belajar dan kegiatan pribadi.

Prestasi belajar adalah usaha maksimal yang dicapai oleh seseorang setelah melaksanakan usaha-usaha belajar. Bukti keberhasilan yang telah dicapai oleh seseorang akan diberikan nilai yang penilaianya dapat berupa angka atau huruf. Seorang anak yang memiliki prestasi belajar tinggi dapat dikatakan bahwa anak mampu menguasai pembelajaran yang diberikan di bangku sekolah, sebaliknya seorang anak yang memiliki prestasi belajar rendah akan dapat diartikan bahwa anak tidak mampu menguasai pembelajaran yang diajarkan disekolah. Salah satu faktor yang mempengaruhi prestasi belajar adalah manajemen waktu, terkait dengan manajemen waktu yang diterapkan oleh seseorang dalam pengelolaan waktu.

\section{RUMUSAN MASALAH}

Dengan mempertimbangkan latar belakang yang telah diutarakan diatas kami berinisiatif untuk membentuk pengabdian masyarakat bagi para siswa
SMP Arraisiyah Pamulang,Tangerang Selatan.

\section{TUJUAN PELAKSANAAN}

1.Membantu memberikan arahan manfaat manajemen waktu kepada siswa.

2. Memberikan semangat dan motivasi kepada para siswa agar dapat meningkatkat prestasi belajar melalui manajemen waktu.

\section{TINJAUAN PUSTAKA}

\section{Pengertian manajemen waktu}

Manajemen waktu sebagai pengelolaan waktu dimana individu menetapkan terlebih dahulu kebutuhan dan keinginan kemudian menyusunya berdasarkan segi urutan kepentingan. Maksudnya bahwa terdapat aktivitas khusus yaitu penetapann tujuan untuk mencapai kebutuhan dan keinginan dengan memprioritaskan tugas yang perlu diselesaikan. Tugas yang sepenuhnya penting kemudian dicocokkan dengan waktu dan sumber yang tersedia melaluai perencanaan, penjadwalan, pembuatan daftar.

Manajemen waktu memiliki peranan besar dalam keberhasilan belajar siswa. Siswa yang tidak memiliki pemahaman manajemen waktu ditandai dengan perencanaan yang tidak terorganisasi, tidak jelas, tidak konsisten, tidak ada tujuan, dan kurang disiplin dalam menggunakan 


\section{JURNAL ABDIMAS

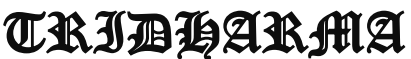

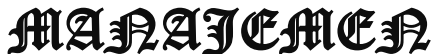

P-ISSN 0000-0000 , E-ISSN 0000-0000

Jurnal ABDIMAS Vol. 1,No.1, Agustus 2019, Hal (84-91)

@Prodi Manajemen Fakultas Ekonomi Universitas Pamulang

Email: abdimasjurnal.unpam@ gmail.com Telp: (021) 741-2566 waktu. Menanamkan sikap tanggung jawab dan disiplin dalam menyelesaikan tugas sesuai jadwal yang ditentukan, akan menjadikan siswa mampu mencapai target belajar dengan mencapai hasil yang optimal. Menurut Mujiyono, dkk (2009: 5) manajemen waktu adalah perencanaan, pengorganisasian, penggerakan, dan pengawasan produktivitas waktu. Sejalan dengan hal tersebut Purwanto (2008: 6) berpendapat bahwa manajemen waktu adalah proses harian yang digunakan untuk membagi waktu, membuat jadwal, daftar hal-hal yang harus dilakukan, pendelegasian tugas, dan sistem lain yang membantu untuk menggunakan waktu secara efektif.

\section{Faktor-faktor yang mempengaruhi manajemen waktu}

Rahardi (2009) menjelaskan beberapa faktor yang menentukan tercapainya proses manajemen waktu siswa, antara lain:

a. Faktor dalam diri yang melakukan kesalahan.

Faktor ini menjadi faktor utama.Setiap manusia belajar dari kesalahan hidupnya. Dengan manajemen, manusia meminimalisir kesalahan dimasa lampau.

b.Faktor lingkungan sekolah

Pada dasarnya lingkungan sekolah menjadi barometer kreativitas siswa. Dengan fasilitas sekolah yang memadai, siswa mampu menimba ilmu secara otodidak.
3. Hubungan antara Manajemen Waktu dengan Prestasi Belajar pada Mahasiswa

Pada hakikatnya setiap orang memiliki manajemen waktu, sehingga tiap mahasiswa mempunyai manajemen waktu yang kemungkinan terdapat perbedaan antara mahasiswa satu dengan yang lainnya. Perbedaan tersebut akan mempengaruhi proses belajar dari mahasiswa sehingga hasil prestasi yang didapatkan juga berbeda. Menurut Wikel (2006) perbedaan prestasi belajar disebabkan oleh adanya faktor eksternal dan faktor internal. Faktor internal adalah cara atau kebiasaan belajar yang diterapkan oleh individu agar prestasi belajarnya dapat berhasil dengan baik, tentu diperlukan suatu strategi yang baik yaitu dengan cara manajemen waktu dengan sebaikbaiknya,semakin individu dalam melakukan manajemen waktunya dengan baik maka akan semakin baik pula prestasi yang akan diperoleh. Sedangkan faktor eksternal adalah lingkungan rumah atau lingkungan sekolah. Faktor linglungan mempengaruhi sikap dan interaksi dengan lingkungan. Tanpa adanya dukungan lingkungan, individu dalam melakan aktivitasnya baik sehari-hari maupun kegiatan belajar akan menemui hambatan dalam proses mencapai prestasi belajar, karena lingkungan belajar berfungsi sebagai stimulus. Jadi jika stimulus itu baik maka akan mendorong dan memperlancar proses 


\section{JURNAL ABDIMAS

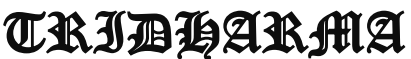

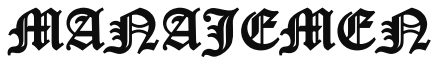

P-ISSN 0000-0000, E-ISSN 0000-0000

Jurnal ABDIMAS Vol. 1,No.1, Agustus 2019, Hal (84-91)

@Prodi Manajemen Fakultas Ekonomi Universitas Pamulang

Email: abdimasjurnal.unpam@ gmail.com Telp: (021) 741-2566 belajar siswa kearah yang lebih baik. Sebaliknya jika stimulus jelek maka akan menjadi hambatan atau kendala dalam kegiatan belajarnya.

Hasmyani (2004) dalam penelitian mengungkap tentang prestasi belajar, pada penelitiannya yang telah dilakukan menyimpulkan ada hubungan positif yang signifikan antara pengisian waktu luang dengan prestasi belajar pada siswa sekolah dasar, semakin efektif pengisian waktu luang, semakin tinggi prestasi belajar. Hal ini mendukung manajemen waktu yang salah satu aspeknya terdapat pengelolaan waktu. Didukung penelitian Supriyono (2003) tentang pemanfaatan waktu luang dan prestasi belajar matematika murid Sekolah Dasar kotamadya Palangkaraya.

\section{METODE PELAKSANAAN}

Metode pelaksanaan pengabdian ini dilakukan dalam beberapa kegiatan yaitu tahap survei yaitu sosialisasi dilakukan dengan menyusun berbagai hal yang akan disampaikan pada saat kegiatan pengabdian yang akan dilakukan yang meliputi: penyusunan materi yang akan diberikan, penyusunan jadwal pemberian materi, pembagian tugas tim pengabdian dan survei ke lokasi pengabdian. Tahap sosialisasi yaitu sebelum kegiatan pengabdian dilaksanakan terlebih dahulu dilakukan tahap sosialisasi yaitu melakukan silaturahmi dengan pimpinan sekolah, menyampaikan maksud dan tujuan pengabdian ini. Pada tahap ini juga dilakukan jalinan kerjasama dan menentukan jadwal kegiatan pengabdian. Tim pelaksana kegiatan pengabdian pada masyarakat adalah dosen Fakultas Ekonomi jurusan manajemen sebanyak 10 orang. Tim pengabdian memberikan materi tentang Manajemen waktu terhadap peningkatan prestasi belajar di sekolah di sekolah SMP Arraisiyah Pamulang,Tangerang Selatan.

\section{HASIL DAN PEMBAHASAN}

Pengabdian Masyarakat (LPPM) Universitas Pamulang yang dilakukan oleh dosen-dosen program studi Manajemen telah berjalan dengan lancar dan mendapat sambutan hangat dari Pihak sekolah termasuk siswa-siswa yang mendapatkan materi. Semakin tinggi manajemen waktu maka akan semakin tinggi prestasi belajar seseorang. Begitupun sebaliknya, semakin rendah manajemen waktu maka akan semakin rendah juga prestasi belajar seseorang. Manajemen waktu adalah dimana individu menetapkan terlebih dahulu kebutuhan dan keinginan kemudian menyusunnya berdasarkan segi urutan kepentingan, maksudnya terdapat aktivitas khusus yaitu penetapan tujuan untuk mencapai kebutuhan dan keinginan dengan memprioritaskan tugas yang perlu diselesaikan. Tugas-tugas yang seharusnya penting kemudian disesuaikan dengan waktu dan sumber yang tersedia melalui perencanaan, penjadwalan, pembuatan daftar, pengorganisasian dan pendekatan terhadap tugas. individu yang mempunyai manajemen waktu yang baik tentunya akan menyelesaikan tugas sesuai dengan batas waktu yang telah 


\section{JURNAL ABDIMAS

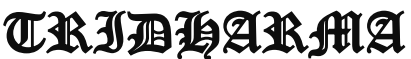

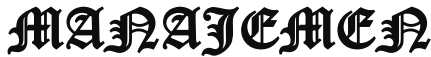

P-ISSN 0000-0000 , E-ISSN 0000-0000

Jurnal ABDIMAS Vol. 1,No.1, Agustus 2019, Hal (84-91)

@Prodi Manajemen Fakultas Ekonomi Universitas Pamulang

Email: abdimasjurnal.unpam@gmail.com Telp: (021) 741-2566 direncanakan, sehingga prestasi belajar juga bertambah baik.

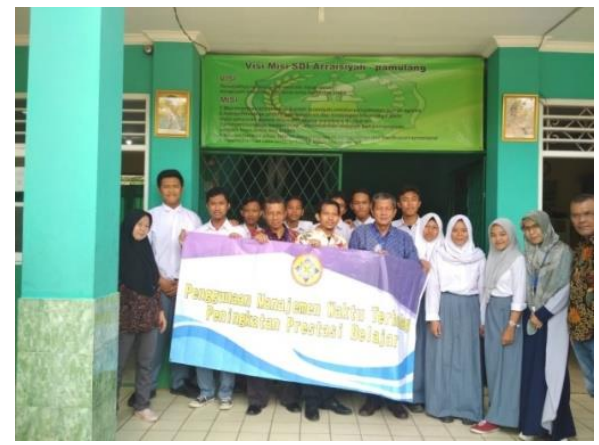

Peranan manajemen waktu sangat diperlukan dalam kegiatan belajar, karena manajemen waktu merupakan salah satu faktor intern yang mempengaruhi hasil belajar. Wikel (2006) mengatakan "perbedaan prestasi belajar disebabkan oleh adanya faktor eksternal dan faktor internal. Faktor internal salah satunya adalah cara atau kebiasaan belajar yang diterapkan oleh individu agar prestasi belajarnya dapat berhasil dengan baik, tentu diperlukan suatu strategi yang baik yaitu dengan cara manajemen waktu dengan sebaikbaiknya, semakin individu dalam melakukan manajemen waktunya dengan baik maka akan semakin baik pula prestasi yang akan diperoleh”. Maka dengan individu melakukan usaha cara belajar yang efektif akan mencapai tujuan belajar yaitu tercapainya prestasi belajar sesuai yang diharapkan.

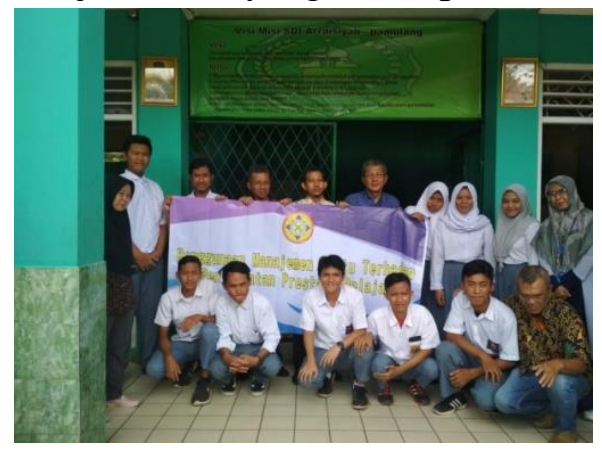

$\begin{array}{ccr}\text { Harapan } & \text { kami } & \text { dengan } \\ \text { pengabdian ini dapat membuka }\end{array}$ wawasan para siswa yang diperoleh pada Pengabdian Masyarakat kali ini diharapkan mampu memberikan semangat baru bagi kita dalam menyampaikan materi dan motivasi serta berkontribusi bagi generasi muda, baik dilingkungan sekolah, kampus dan keluarga.

\section{KESIMPULAN DAN SARAN}

Kesimpulan

Parasiswa belum memahami dan belum mampu menerapkan manajemen waktu dalah kehidupan sehari-hari. Dalam pengaksesan media sosial terkadang siswa masih tidak terkontrol. Mereka cenderung menghabiskan waktu lebih lama di media sosial untuk mengakses konten -konten yang bernuansa hiburan. Para siswa sangat jarang menggunakan media sosial untuk mengakses konten dunia pendidikan.

Saran

Setelah pengabdian ini diharapkan para siswa dapat membuat manajemen waktu dalam keseharian dan menerapkannya. Tim pengabdian agar terus melakukan kegiatan-kegiatan serupa secara berkesinambungan di masa yang akan datang

\section{DAFTAR PUSTAKA}

Hasmyani, B.2004. Prestasi Belajar Ditinjau Dari Kebiasaan Belajar Dan Pengisian Waktu Luang Pada Siswaa Sekolah Dasar Karangwuni 1 Yogyakarta. Tesis. Yogyakarta: Program Pascsarjana UGM. 


\section{JURNAL ABDIMAS

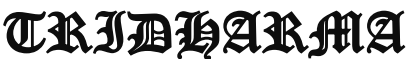

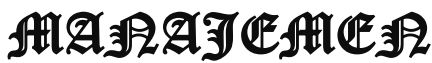

P-ISSN 0000-0000, E-ISSN 0000-0000

Jurnal ABDIMAS Vol. 1,No.1, Agustus 2019, Hal (84-91)

@ Prodi Manajemen Fakultas Ekonomi Universitas Pamulang

Email: abdimasjurnal.unpam@ gmail.com Telp: (021) 741-2566

Pasaribu, V. L. D., Susanti, F., \& Hartuti, E. T. K. (2019). MEMOTIVASI SISWA DAN SISWI SMK LETRIS INDONESIA DI DALAM MENENTUKAN PILIHAN UNTUK MELANJUTKAN PENDIDIKAN ATAU BEKERJA SETELAH LULUS SEKOLAH. Jurnal Pengabdian Dharma Laksana, 1(2), 161-172.

Rohadi. (2008). Pengaruh Manajemen Waktu dan Motivasi Mengajar terhadap Kompetensi Profesional Guru di Sekolah Menengah Atas Kota Pekalongan. Tesis. Semarang: Program Studi Manajemen Pendidikan Pogram Pascasarjana Universitas Negeri Semarang

Sari, A.N. 2010. Hubungan Antara Manajemen Waktu Dengan Prokratinasi Akademik Pada Mahasiswa Yang Berwirausaha. Skripsi. Surakarta. Fakultas Psikologi UMS.

Slamet. (2003). Belajar dan FaktorFaktor yang Mempengaruhinya. Jakarta: Rineka Cipta.

Winkel, W.S dan Hastuti, Sri. (2004). Psikologi Pengajaran.Yogyakarta: Media Abadi. 